\title{
Damage Probability Assessment of Hospital Buildings in Yogyakarta, Indonesia as Essential Facility due to an Earthquake Scenario
}

\author{
Yunalia Muntafi ${ }^{1,3^{\star}}$, Nobuoto Nojima ${ }^{2}$, Atika Ulfah Jamal ${ }^{3}$ \\ ${ }^{1}$ Department of Engineering Science, Gifu University, Gifu, JAPAN \\ 1-1 Yanagido, Gifu 501-1193, Japan \\ ${ }^{2}$ Department of Civil Engineering Science, Gifu University, Gifu, JAPAN \\ 1-1 Yanagido, Gifu 501-1193, Japan \\ ${ }^{3}$ Department of Civil Engineering, Universitas Islam Indonesia, Yogyakarta, INDONESIA \\ Jalan Kaliurang km. 14,5 Sleman, Yogyakarta \\ "Corresponding authors: yunalia@uii.ac.id
}

SUBMITTED 13 January 2020 REVISED 4 April 2020 ACCEPTED 25 August 2020

\begin{abstract}
Indonesia is a country located in an earthquake-prone region, and is characterized by significantly increased peak ground acceleration value. The seismic hazard map of Indonesia stated in SNI 1726-2012 and the current statistics published by PUSGEN in 2017 emphasized on the significance of assessing building damage probabilities, especially for essential structures in Yogyakarta. However, immediate action is required to handle response and recovery operations during and after a disaster. The aim of this study, therefore, is to ascertain the vulnerability and damage probability of hospital buildings in Yogyakarta by employing the 2006 earthquake scenario, where reports showed the destruction of over 156,000 houses and other structures. Furthermore, a Hazard-US (HAZUS) method was used for structural analysis, while a ground motion prediction equation was adopted to produce the building response spectra, following the characteristics of the earthquake incidence. The vital step in this assessment involves building type classification and identification of seismic design levels. However, the damage tendency of buildings is determined using the peak building response, which ensures the generation of capacity curves. The most significant findings on building damage probability value were less than $15 \%$ in each damage state (slight, moderate, extensive, complete). In addition, the optimum value was achieved at the minimum level of damage (minor), while the least values were recorded at the highest damage level (complete).
\end{abstract}

KEYWORDS Earthquake; Ground Motion; HAZUS Method, Vulnerability Assessment; Damage Assessment.

(C) The Author(s) 2020. This article is distributed under a Creative Commons Attribution-ShareAlike 4.0 International license.

\section{INTRODUCTION}

Based on numerous evidence, Indonesia is known to frequently experience major earthquake damages. Specifically, Yogyakarta is one of the heavily populated cities on Java island observed to have suffered a severe devastating earthquake on May 27, 2006 in a magnitude of 6.3 Mw. The casualty rate and economic loss on buildings and infrastructures were high, and a report by Bappenas (2006) showed a death toll of over 5,700, while those injured exceeded 60,000. Furthermore, total damages and losses in the residential buildings reached $52.4 \%$, total estimated economic loss was 29.1 trillion rupiahs. Therefore, the government applied scientific progress to understanding the earthquake sources by analyzing the seismic map of Indonesia. This data served as a basis for geomorphology and the designs for earthquakeresistant buildings. The National Center for Earthquake Studies (PuSGen) and the Indonesia seismic hazard published maps displaying
Earthquake Resistant Building code (SNI 17262012). Figure 1 shows a significantly higher peak ground acceleration (PGA) value in Yogyakarta region compared to the values in SNI 1726-2002, from $0.15 \mathrm{~g}$ to $0.2-0.4 \mathrm{~g}$. This increase provided a distintitive damage impact, especially for the buildings designed using outdated standards.

Previous studies showed the application of seismicity to residential buildings in Indonesia, including a research by Saputra (2012), Kurniawandy, (2015), and Bawono (2016). Faizah et al. (2017) conducted a rapid assessment on the vulnerability of the Muhammadiyah school buildings in Kasihan and Bantul districts of Yogyakarta using the Rapid Visual Screening (RVS) method from FEMA 154-2002. Therefore, the analysis was performed through visual observation, using the assessment form on RVSFEMA-2002. A similar research was recently conducted by Gentile et al. (2019), where a rapid 
visual survey was carried out on multi-hazard risk prioritization and numerical fragility was implemented in school buildings at Banda Aceh, Indonesia.
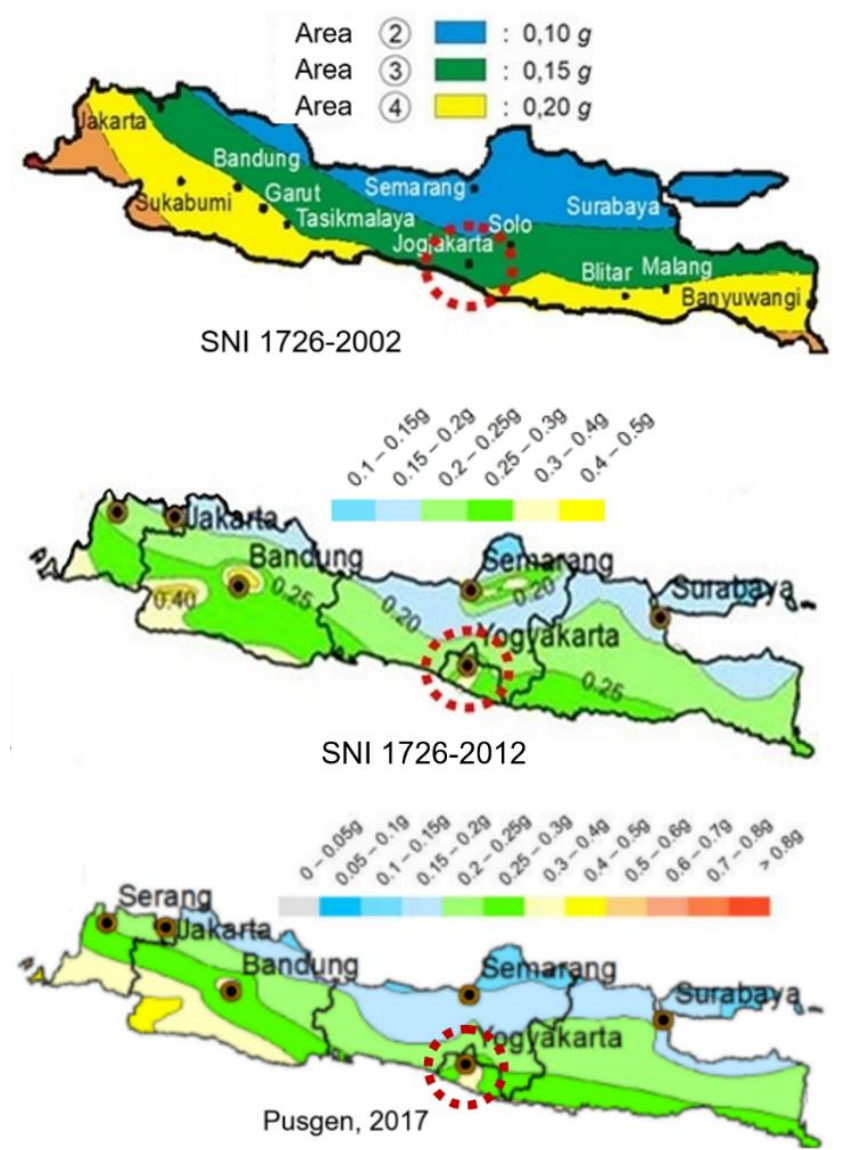

Figure 1. Peak Ground Acceleration (PGA) Map of Java Island for $10 \% 50 \mathrm{yr}$ with $5 \%$ damping

According to the Hazards United States Multi Hazards (HAZUS-MH) MR4 on FEMA (2003), hospitals are classified as essential facilities charged with the responsibility to provide health community care services, and are expected to function in disaster emergency occasions.

However, previous literature reviews showed the damage inflicted on innumerable hospital buildings, with devastating impact levels. This current study is a follow up research of the report by Muntafi, (2016), which focused on the mitigation efforts related to catastrophic incidence in densely populated earthquakeprone areas. Therefore, this study aims to determine the vulnerability of hospital buildings, alongside the structural quality and earthquake risk perception for all damage states. The research population used include hospital buildings in Yogyakarta city, Indonesia.

\section{METHODS}

This study adopts the Hazards USA (HAZUS) Earthquake Model, known to deal with all aspects of the big cities. However, there is no specific technique to evaluate the vulnerability of numerous building types. Therefore, this method is designed to produce economic loss estimates for local governments and policymakers to apply in the determination of contingency plans (NIBS, 2002).

The procedure was preceded with building identification, based on HAZUS model type and categorization, as well as seismic design level classification, analysis of response spectra using a moderate to strong earthquake of $6.3 \mathrm{Mw}$ by the 2006 Yogyakarta earthquake scenario, and also by generating the capacity curve to obtain the peak building response from the HAZUS fragility curve method. The result, therefore, show the damage probability of each building obtained based on the value of the peak response.

\subsection{Description of The Study Area}

Yogyakarta was selected as the study area due to the significant rise in PGA values. In addition, this highly populated city experienced a devastating earthquake in 2006, and destruction of over 156,000 was recorded (Elnashai et al., 2006). Preliminary surveys led to the selection of fifteen hospitals with locations presented in Figure 2. 


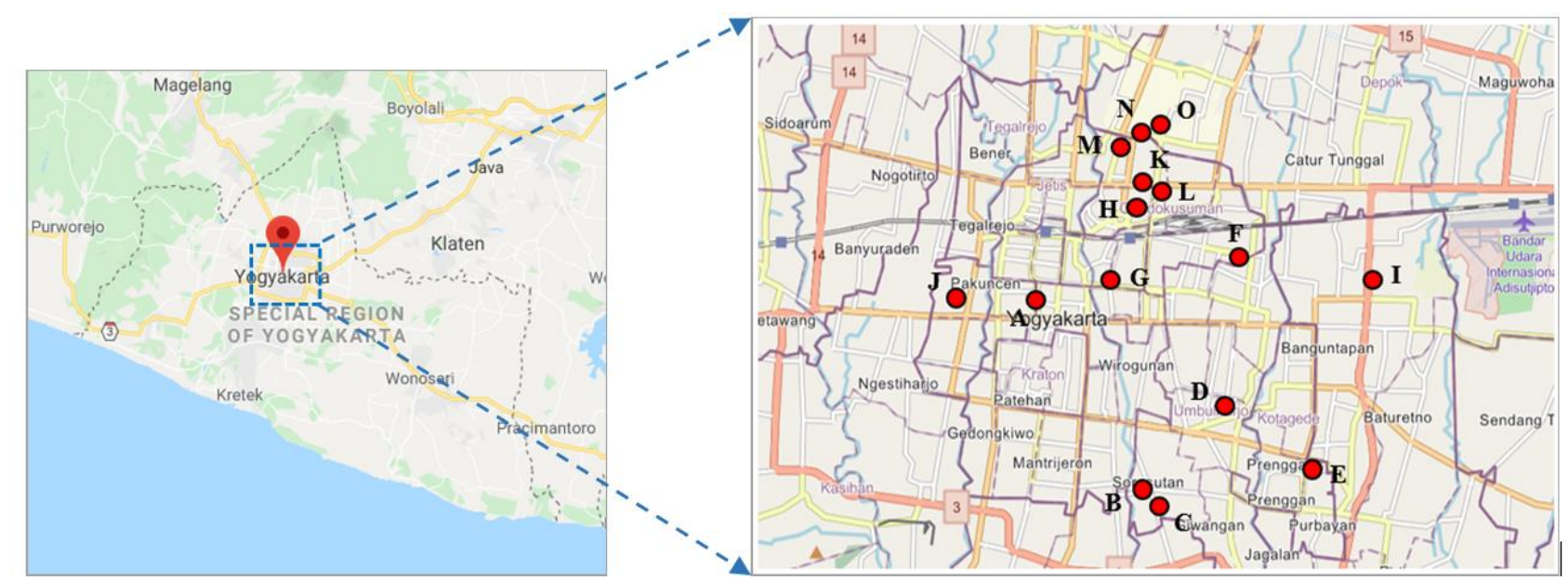

Figure 2. Map of building locations (from google maps accessed on 2019 and detailed with ArcGIS Pro 2.5.0 advancedlicensed)

\subsection{Earthquake Response Spectra}

Several ground motion prediction equations or attenuation relationship models have been developed across the globe but the magnitude, distance and source mechanism data of the 2006 Yogyakarta earthquake correspond to the attenuation equation proposed by Boore et al., (1997) as follows:

$$
\begin{aligned}
\operatorname{Ln}[Y]= & b_{1}+b_{2}(M-6)+b_{3}(M-6)^{2}+ \\
& b_{5} \operatorname{Ln}(r)+b v \operatorname{Ln} \frac{V_{S}}{V_{A}}
\end{aligned}
$$

$r=\sqrt{r_{j b}^{2}+h^{2}}$

$$
b_{1}=\left\{\begin{array}{l}
b_{1 s s}: \text { for strike slip earthquakes } \\
b_{1 R V}: \text { for reverse slip earthquakes } \\
b_{1 \text { All }}: \text { if mechanism is not specified }
\end{array}\right\}
$$

Where, $Y$ denotes peak horizontal acceleration or pseudo acceleration response (g), $M$ is moment magnitude $(\mathrm{Mw}), r_{j b}$ represents the closest horizontal distance to the surface projection of the rupture plane $(\mathrm{km}), V_{s}$ is average shear-wave velocity to $30 \mathrm{~m}$ below ground surface $(\mathrm{m} / \mathrm{sec})$, and $b_{1}, b_{2}, b_{3}$, and $b_{5}$ are coefficients to estimate pseudo acceleration response spectra as shown in Table 1.

The equation model used was based on data from Western North America type of shallow earthquake. In addition, the parameters utilized include magnitude of $5.5-7.5 \mathrm{Mw}$, less than 80km distance as well as strike-slip, reverse-slip, and unspecified faulting styles. Subsequently, the spectral acceleration $(\mathrm{g})$ of each period on Table 1 were obtained using Equation 1 and plotted as a function of spectral displacement by converting the units of $g$ (the acceleration due to Earth's gravity, equivalent to g-force) to inches with the NIBS (2002) Equation (3) below:

$\mathrm{S}_{\mathrm{d}}[\mathrm{T}]=9.8 \cdot \mathrm{S}_{\mathrm{a}}[\mathrm{T}] \cdot \mathrm{T}^{2}$

where $S_{d}$ is spectral displacement $(\mathrm{g}), S_{a}$ is spectral acceleration (in), and $T$ is time period (sec).

\subsection{Building Model Type}

Table 2 depicts the categorization of buildings into 36 groups according to the HAZUS-99 methodology described in FEMA 178 classification system, NEHRP Handbook for the Seismic Evaluation of Existing Buildings (FEMA, 1992).

The selected structures comprised a variety of reinforced concrete moment resisting frames Identified as $\mathrm{C} 1$ by the HAZUS system. According to the seismic resistance code design and prior to collapse during earthquakes, frame members of older buildings tend to undergo brittle failure. However, modern structures in zones of high seismicity exhibit ductile behavior and are more likely to undergo large deformation. 
Table 1. The coefficient of attenuation proposed by Boore-Joyner-Fumal 1997

\begin{tabular}{llllllllll}
\hline Period (s) & $b_{\text {1ss }}$ & $b_{\text {1rs }}$ & $b_{\text {1all }}$ & $b_{2}$ & $b_{3}$ & $b_{5}$ & $b v$ & $V_{A}$ & $h$ \\
\hline 0.00 & -0.313 & -0.117 & -0.242 & 0.527 & 0.000 & -0.778 & -0.371 & 1396 & 5.57 \\
0.10 & 1.006 & 1.087 & 1.059 & 0.753 & -0.226 & -0.934 & -0.212 & 1112 & 6.27 \\
0.20 & 0.999 & 1.17 & 1.089 & 0.711 & -0.207 & -0.924 & -0.292 & 2118 & 7.02 \\
0.30 & 0.598 & 0.803 & 0.700 & 0.769 & -0.161 & -0.893 & -0.401 & 2133 & 5.94 \\
0.40 & 0.212 & 0.423 & 0.311 & 0.831 & -0.12 & -0.867 & -0.487 & 1954 & 4.91 \\
0.50 & -0.122 & 0.087 & -0.025 & 0.884 & -0.09 & -0.846 & -0.553 & 1782 & 4.13 \\
0.60 & -0.401 & -0.203 & -0.314 & 0.928 & -0.069 & -0.830 & -0.602 & 1644 & 3.57 \\
0.75 & -0.737 & -0.562 & -0.661 & 0.979 & -0.046 & -0.813 & -0.653 & 1507 & 3.07 \\
1.00 & -1.133 & -1.009 & -1.080 & 1.036 & -0.032 & -0.798 & -0.698 & 1406 & 2.90 \\
1.50 & -1.552 & -1.538 & -1.550 & 1.085 & -0.044 & -0.796 & -0.704 & 1479 & 3.92 \\
2.00 & -1.699 & -1.801 & -1.743 & 1.085 & -0.085 & -0.812 & -0.655 & 1795 & 5.85 \\
\hline
\end{tabular}

Table 2. Building model types based on HAZUS-99 document

\begin{tabular}{|c|c|c|c|c|c|c|}
\hline \multirow{3}{*}{ No } & \multirow{3}{*}{ Label } & \multirow{3}{*}{ Description } & \multicolumn{4}{|c|}{ Height } \\
\hline & & & \multicolumn{2}{|c|}{ Range } & \multicolumn{2}{|c|}{ Typical } \\
\hline & & & Name & Stories & Stories & Feet \\
\hline 1 & $\mathrm{~W} 1$ & Wood, Light Frame ( $\leqslant 5,000$ sq. ft.) & & $1-2$ & 1 & 14 \\
\hline 2 & $\mathrm{~W} 2$ & Wood, Commercial and Industrial (> 5,000 sq. ft.) & & All & 2 & 24 \\
\hline 3 & S1L & \multirow{3}{*}{ Steel Moment Frame } & Low-Rise & $1-3$ & 2 & 24 \\
\hline 4 & S1M & & Mid-Rise & $4-7$ & 5 & 60 \\
\hline 5 & $\mathrm{~S} 1 \mathrm{H}$ & & High-Rise & +8 & 13 & 156 \\
\hline 6 & S2L & \multirow{3}{*}{ Steel Brace Frame } & Low-Rise & $1-3$ & 2 & 24 \\
\hline 7 & S2M & & Mid-Rise & $4-7$ & 5 & 60 \\
\hline 8 & $\mathrm{~S} 2 \mathrm{H}$ & & High-Rise & +8 & 13 & 156 \\
\hline 9 & S3 & Steel Light Frame & & All & 1 & 15 \\
\hline 10 & S4L & \multirow{3}{*}{$\begin{array}{l}\text { Steel Frame with Cast-in-Place Concrete } \\
\text { Shear Walls }\end{array}$} & Low-Rise & $1-3$ & 2 & 24 \\
\hline 11 & S4M & & Mid-Rise & $4-7$ & 5 & 60 \\
\hline 12 & $\mathrm{~S} 4 \mathrm{H}$ & & High-Rise & +8 & 13 & 156 \\
\hline 13 & S5L & \multirow{3}{*}{$\begin{array}{l}\text { Steel Frame with Unreinforced Masonry } \\
\text { Infill Walls }\end{array}$} & Low-Rise & $1-3$ & 2 & 24 \\
\hline 14 & S5M & & Mid-Rise & $4-7$ & 5 & 60 \\
\hline 15 & $\mathrm{~S} 5 \mathrm{H}$ & & High-Rise & +8 & 13 & 156 \\
\hline 16 & C1L & \multirow{3}{*}{ Concrete Moment Frame } & Low-Rise & $1-3$ & 2 & 20 \\
\hline 17 & $\mathrm{C} 1 \mathrm{M}$ & & Mid-Rise & $4-7$ & 5 & 50 \\
\hline 18 & $\mathrm{C} 1 \mathrm{H}$ & & High-Rise & +8 & 12 & 120 \\
\hline 19 & $\mathrm{C} 2 \mathrm{~L}$ & \multirow{3}{*}{ Concrete Shear Walls } & Low-Rise & $1-3$ & 2 & 20 \\
\hline 20 & $\mathrm{C} 2 \mathrm{M}$ & & Mid-Rise & $4-7$ & 5 & 50 \\
\hline 21 & $\mathrm{C} 2 \mathrm{H}$ & & High-Rise & +8 & 12 & 120 \\
\hline 22 & C3L & \multirow{3}{*}{$\begin{array}{l}\text { Concrete Frame with Unreinforced Masonry } \\
\text { Infill Walls }\end{array}$} & Low-Rise & $1-3$ & 2 & 20 \\
\hline 23 & C3M & & Mid-Rise & $4-7$ & 5 & 50 \\
\hline 24 & $\mathrm{C} 3 \mathrm{H}$ & & High-Rise & +8 & 12 & 120 \\
\hline 25 & PC1 & Precast Concrete Tilt-Up Walls & & All & 1 & 15 \\
\hline 26 & PC2L & \multirow{3}{*}{$\begin{array}{l}\text { Precast Concrete Frame with Concrete } \\
\text { Shear Walls }\end{array}$} & Low-Rise & $1-3$ & 2 & 20 \\
\hline 27 & PC2M & & Mid-Rise & $4-7$ & 5 & 50 \\
\hline 28 & $\mathrm{PC} 2 \mathrm{H}$ & & High-Rise & +8 & 12 & 120 \\
\hline 29 & RM1L & \multirow{2}{*}{$\begin{array}{l}\text { Reinforced Masonry Bearing Walls with Wood } \\
\text { or Metal Deck Diaphragms }\end{array}$} & Low-Rise & $1-3$ & 2 & 20 \\
\hline 30 & RM1M & & Mid-Rise & $4+$ & 5 & 50 \\
\hline 31 & RM2L & \multirow{3}{*}{$\begin{array}{l}\text { Reinforced Masonry Bearing Walls with Precast } \\
\text { Concrete Diaphragms }\end{array}$} & Low-Rise & $1-3$ & 2 & 20 \\
\hline 32 & RM2M & & Mid-Rise & $4-7$ & 5 & 50 \\
\hline 33 & $\mathrm{RM} 2 \mathrm{H}$ & & High-Rise & +8 & 12 & 120 \\
\hline 34 & URML & \multirow{3}{*}{$\begin{array}{l}\text { Unreinforced Masonry Bearing Walls } \\
\text { Mobile Homes }\end{array}$} & Low-Rise & $1-2$ & 1 & 15 \\
\hline 35 & URMM & & Mid-Rise & $3+$ & 3 & 35 \\
\hline 36 & $\mathrm{MH}$ & & & All & 1 & 10 \\
\hline
\end{tabular}




\subsection{Seismic Design Level}

During an earthquake, damages occur due to ground shaking and ground failure. This study, therefore, aims to determine the seismic design level from the classification by Muntafi (2018), and detailed descriptions from Eleftheriadou et al., (2014) and also the year of construction and building code of each structure as shown in Table 3.

\subsection{Building Damage State and Cumulative Probability}

The HAZUS system predicted and classified structural and nonstructural damage into slight, moderate, extensive, or complete state. Hence, slight structural damage is described as Flexural or shear type hairline cracks in some beams and columns near or within joints of reinforced concrete moment resisting (C1) frames. Moreover, moderate structural damage occurs when most beams and columns exhibit hairline cracks. Larger flexural cracks and concrete spalling Indicates yield capacity has been exceeded while larger shear cracks and spalling tend to be observed in the non-ductile variant. Extensive structural damage refers to a scenario where some frame elements have attained ultimate capacity. This is indicated in ductile frames by large flexural cracks, spalled concrete and buckled main reinforcement, while nonductile frames feature and shear or bond failures at splices as well as broken ties or buckled main reinforcement in columns possibly leading to partial collapse. Furthermore, a complete structural damage implies imminent danger or collapse due to brittle failure or instability in non-ductile frame elements. Approximately $20 \%$ (low-rise), 15\% (mid-rise) and 10\% (high-rise) of C1 buildings in the area are expected to experience this challenge.

The incidence of Ground failure and shaking are known to generally damage the functions of essential structures. These experiences are reported in the HAZUS document as lognormal fragility curves and are used to determine a building's tendency to reach or exceed damage for a specific potential earth science hazard (PESH) parameter, including response spectrum displacement. Therefore, the probability, $d s$, $\left(P\left[S \mid S_{d}\right] ; P\left[M \mid S_{d}\right] ; P\left[E \mid S_{d}\right] ; P\left[C \mid S_{d}\right]\right)$ of the building damage with a specific spectral displacement $\left(S_{d}\right)$ is obtained with the Equation (4) below.

$P\left[d s / S_{d}\right]=\Phi\left[\frac{1}{\beta_{d s}} \ln \left(\frac{s_{d}}{\bar{s}_{d . d s}}\right)\right]$

Where, $P\left[S \mid S_{d}\right], \quad P\left[M \mid S_{d}\right], \quad P\left[E \mid S_{d}\right]$ and $P\left[C \mid S_{d}\right]$ designate a building's cumulative probability to reach or exceed slight, moderate, extensive, or complete damage state, respectively. Meanwhile, $\bar{S}_{d . d s}$ is the spectral displacement median value at the threshold of damage state $(d s)$. In addition, $\beta_{d s}$ is the natural logarithm standard deviation of spectral displacement for $d s$, and $\Phi$ is the function of standard normal cumulative distribution.

Table 3. Building seismic design level classification

\begin{tabular}{lll}
\hline Seismic design level & Year of construction & Description \\
\hline Low-code & before 1991 & $\begin{array}{l}\text { RC buildings with low level or no seismic design, and minimal } \\
\text { detailing quality (using Indonesia Concrete Regulation, PBI 1971 } \\
\text { or earlier) }\end{array}$ \\
\hline & $\begin{array}{l}\text { RC buildings with medium level of seismic design and reasonable } \\
\text { detailing of RC members (using SK SNI T-15-1991-03 or SNI 03- } \\
\text { Moderate-code }\end{array}$ & $\begin{array}{l}\text { 2847-2002 for the RC structure design and SNI 03-1726-2002 for } \\
\text { earthquake resistant designs) }\end{array}$
\end{tabular}

RC buildings with adequate level of seismic design according to

High-code after 2012 the new generation codes and sufficient descriptions for detailing RC members (using SNI 2847:2013 for the RC structure design and SNI 1726:2012 for earthquake resistant building design) 
Subsequently, cumulative damage probabilities are differentiated to obtain the individual values. Based on HAZUS-99, each fragility curve is defined by a median value of the PESH demand parameter, which corresponds to the threshold and variability of a damage state. Figure 3 shows examples of fragility curve patterns for the four damage states.

\section{RESULTS AND DISCUSSION}

\subsection{Capacity of Building}

The building capacity of each hospital structure was evaluated based on the model type, seismic design level, and property age. Also, the curves were assumed to have a range of possible log properties and distributed as a function of the ultimate strength $(A u)$ per curve. The Yield $(D y$, $A y)$ and Ultimate Capacity Point $(D u, A u)$ values per structure were determined using the parameters provided in Table 4 and Figure 4 .

Figure 4 showed the influence of seismic design level and structural height on spectral displacement value. Therefore, higher figures correspond to an older structure standard and a greater amount of building stories, as demonstrated in the graphs. Amongst the five graphics, the properties with mid-rise and low seismic design levels (C1M-Low), including Building $\mathrm{A}$ and $\mathrm{O}$ demonstrated the highest spectral displacement and possibly vulnerability value.

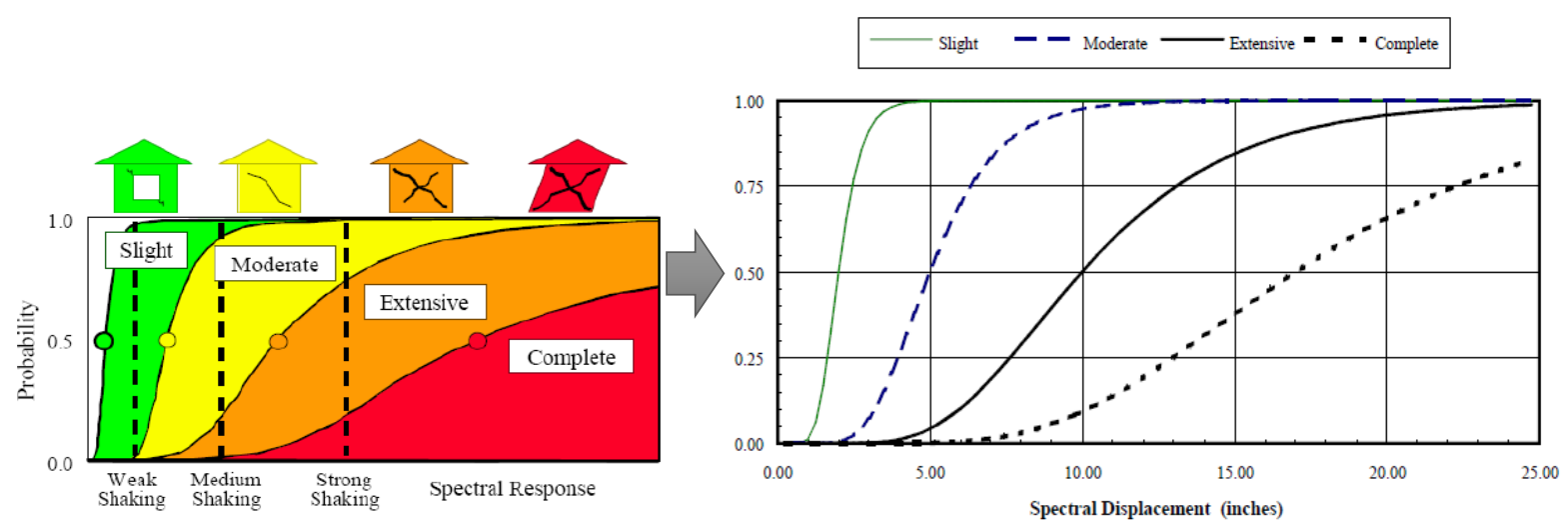

Figure 3. Typical form of fragility curves for slight, moderate, extensive, and complete damage (FEMA, 1999)

Table 4. Capacity curve parameter for hospital buildings based on HAZUS-99 (High/Moderate/Low-code) - Seismic Design Level

\begin{tabular}{lllllll}
\hline \multirow{2}{*}{ Hospital Building } & \multirow{2}{*}{ Building type } & Seismic Design Level & \multicolumn{5}{l}{ Capacity curve parameter } \\
\cline { 5 - 7 } & & & $D y($ in.) & $A y(g)$ & $D u$ (in.) & $A u(g)$ \\
\hline Building A & C1M & Low & 0.43 & 0.078 & 5.19 & 0.234 \\
Building B & C1L & Moderate & 0.29 & 0.187 & 7.04 & 0.562 \\
Building C & C1M & High & 1.73 & 0.312 & 27.65 & 0.937 \\
Building D & C1L & Moderate & 0.29 & 0.187 & 7.04 & 0.562 \\
Building E & C1L & Moderate & 0.29 & 0.187 & 7.04 & 0.562 \\
Building F & C1M & Moderate & 0.86 & 0.156 & 13.83 & 0.468 \\
Building G & C1L & Low & 0.15 & 0.094 & 2.64 & 0.281 \\
Building H & C1L & Low & 0.15 & 0.094 & 2.64 & 0.281 \\
Building I & C1L & Moderate & 0.29 & 0.187 & 7.04 & 0.562 \\
Building J & C1M & Moderate & 0.86 & 0.156 & 13.83 & 0.468 \\
Building K & C1L & Low & 0.15 & 0.094 & 2.64 & 0.281 \\
Building L & C1L & Moderate & 0.29 & 0.187 & 7.04 & 0.562 \\
Building M & C1L & Low & 0.15 & 0.094 & 2.64 & 0.281 \\
Building N & C1L & Low & 0.15 & 0.094 & 2.64 & 0.281 \\
Building O & C1M & Low & 0.43 & 0.078 & 5.19 & 0.234 \\
\hline
\end{tabular}




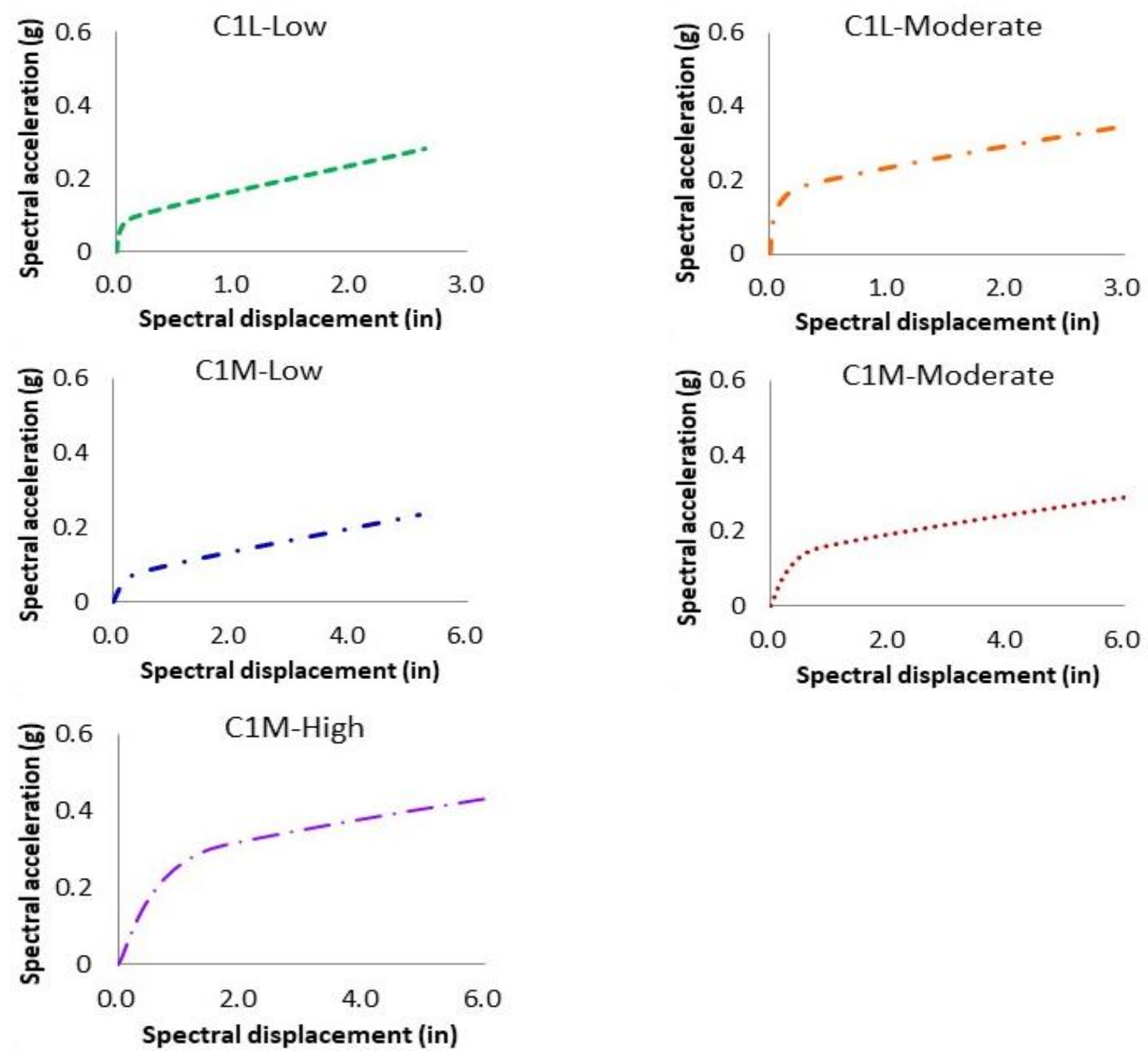

Figure 4. Capacity curve for each typical hospital buildings in Yogyakarta

\subsection{Peak Building Response}

The vulnerability function in HAZUS method for this study was derived from two types of curves, including the capacity and demand or response spectrum. Furthermore, these parameters served as basis for the determination of peak building responses generated per structure, and calculated from Equation (1) and (3). The outcome was estimated as the intersection of both curves, converted into the Sa-Sd relationship using Equation (3), as shown in Figure 5. Meanwhile, Table 5 shows the values for spectral displacement. Figure 5 shows the highest peak spectral acceleration value in Building $\mathrm{B}$ and $\mathrm{C}$, while the least were recorded in $\mathrm{N}$ and $\mathrm{O}$. The coefficients $b, h$, and $V A$ were determined in the selected GMPE, and determined to be involved in conjunction with several parameters, including magnitude, distance, and Vs value. Therefore, buildings evidently closest to the epicenter are relatively most affected with similar earthquake magnitude. 

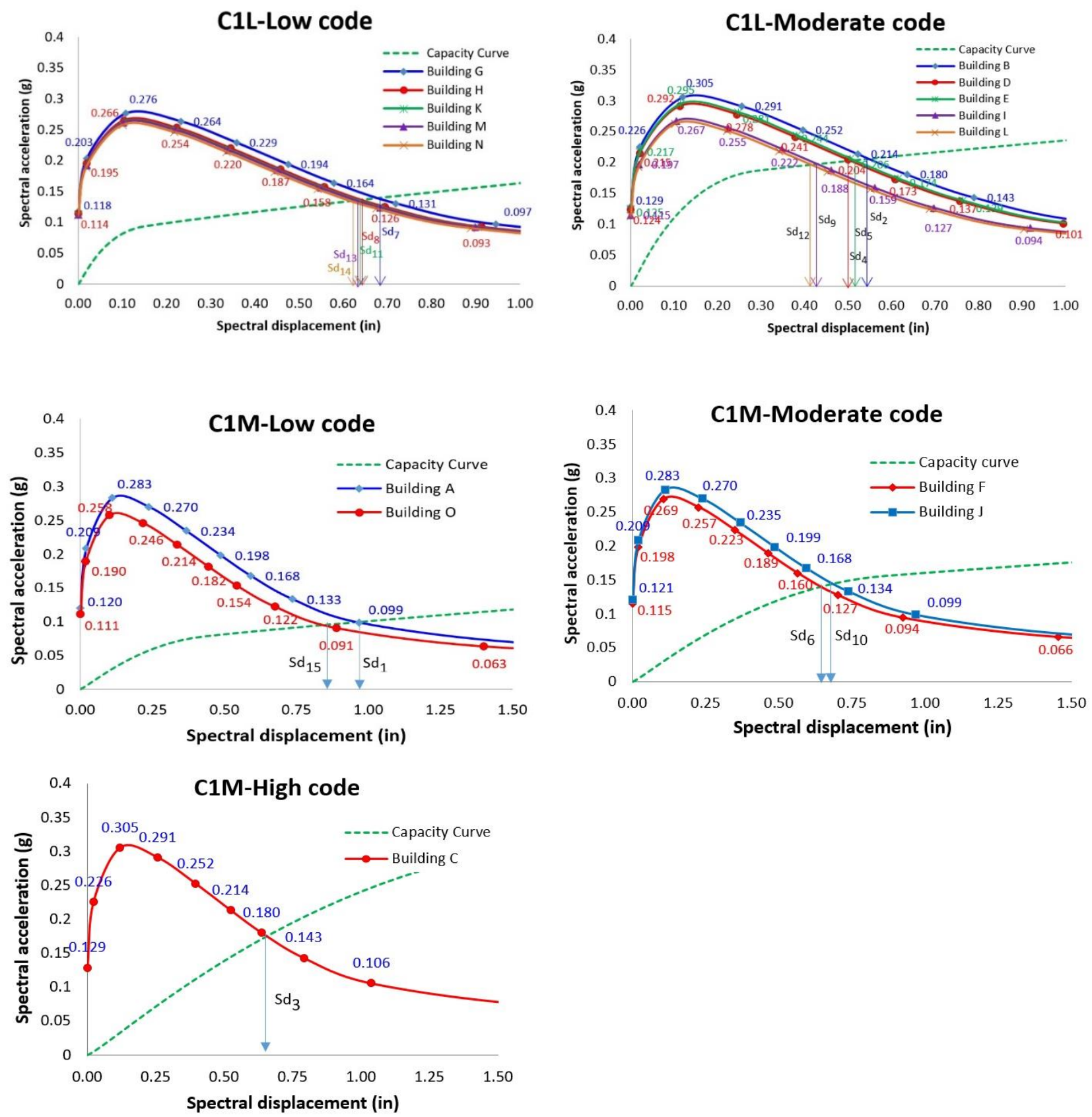

Figure 5. Demand spectrum of each typical hospital buildings

Table 5. Peak response building value per hospital building

\begin{tabular}{lll}
\hline \multirow{2}{*}{ Hospital Building } & \multicolumn{2}{l}{ Peak building response } \\
\cline { 2 - 3 } & Code & Sd (in) \\
\hline Building A & Sd1 & 0.970 \\
Building B & Sd2 & 0.560 \\
Building C & $\mathrm{Sd} 3$ & 0.680 \\
Building D & $\mathrm{Sd} 4$ & 0.518 \\
Building E & $\mathrm{Sd} 5$ & 0.522 \\
Building F & $\mathrm{Sd} 6$ & 0.650 \\
Building G & $\mathrm{Sd} 7$ & 0.680 \\
Building H & $\mathrm{Sd} 8$ & 0.640 \\
\hline
\end{tabular}

\begin{tabular}{lll}
\hline \multirow{2}{*}{ Hospital Building } & \multicolumn{2}{l}{ Peak building response } \\
\cline { 2 - 3 } & Code & Sd (in) \\
\hline Building I & Sd9 & 0.440 \\
Building I & Sd10 & 0.700 \\
Building K & Sd11 & 0.638 \\
Building L & Sd12 & 0.415 \\
Building M & Sd13 & 0.635 \\
Building N & Sd14 & 0.620 \\
Building O & Sd15 & 0.850 \\
& & \\
\hline
\end{tabular}




\subsection{Fragility Curve}

Furthermore, each fragility curve in this research was determined based on a median and lognormal standard deviation $(\beta)$ value in relation to the model type and seismic design level per structure. These parameters were obtained from the cumulative probability calculation result using equation (4). Figure 6 shows the fragility curve for each typical hospital building.

Figure 6 shows the close relationship between the variations of each damage level and the model type, height, as well as seismic design for the building. Furthermore, there were significant differences in the five typical model forms of structures at the same Sd value. Specifically, the shape of the fragility curve has a C1M building type fabricated with high seismic design code, and a tendency to be gentler. Moreover, damage probability in all states emerge only after Sd values above 0.2 inches. This phenomenon is depicted in the illustration with similar structure form of both low concrete moment frames (C1L) and medium level of stories (C1M). Therefore, using a greater code induces a smaller value, particularly in the complete state.

\subsection{Probability of Building Damage}

This parameter was obtained from the cumulative probability calculation using equation (4) for the respective chospital buildings and at each destruction level. Furthermore, all values depend on the median of spectral displacement, lognormal standard deviation, design code, and model-building type. Table 6 shows the computation result for the specific damage state based on the peak building response values of hospital structures, while Figure 7 illustrates the building damage probability.

The matrix depicts a destruction probability value below $15 \%$ per damage state in all hospital buildings. This phenomenon was affiliated with the 2006 Yogyakarta earthquake scenario. Also, structure $G$ has the highest value in all levels, including slight, moderate, extensive, and complete, at $14.903 \%$; $11.018 \%$; $1.431 \%$; and $0.157 \%$, respectively. In addition, a low seismic design level was used despite the short stories (C1L) characteristics of the structures, and the distance to the disaster source was relatively small.
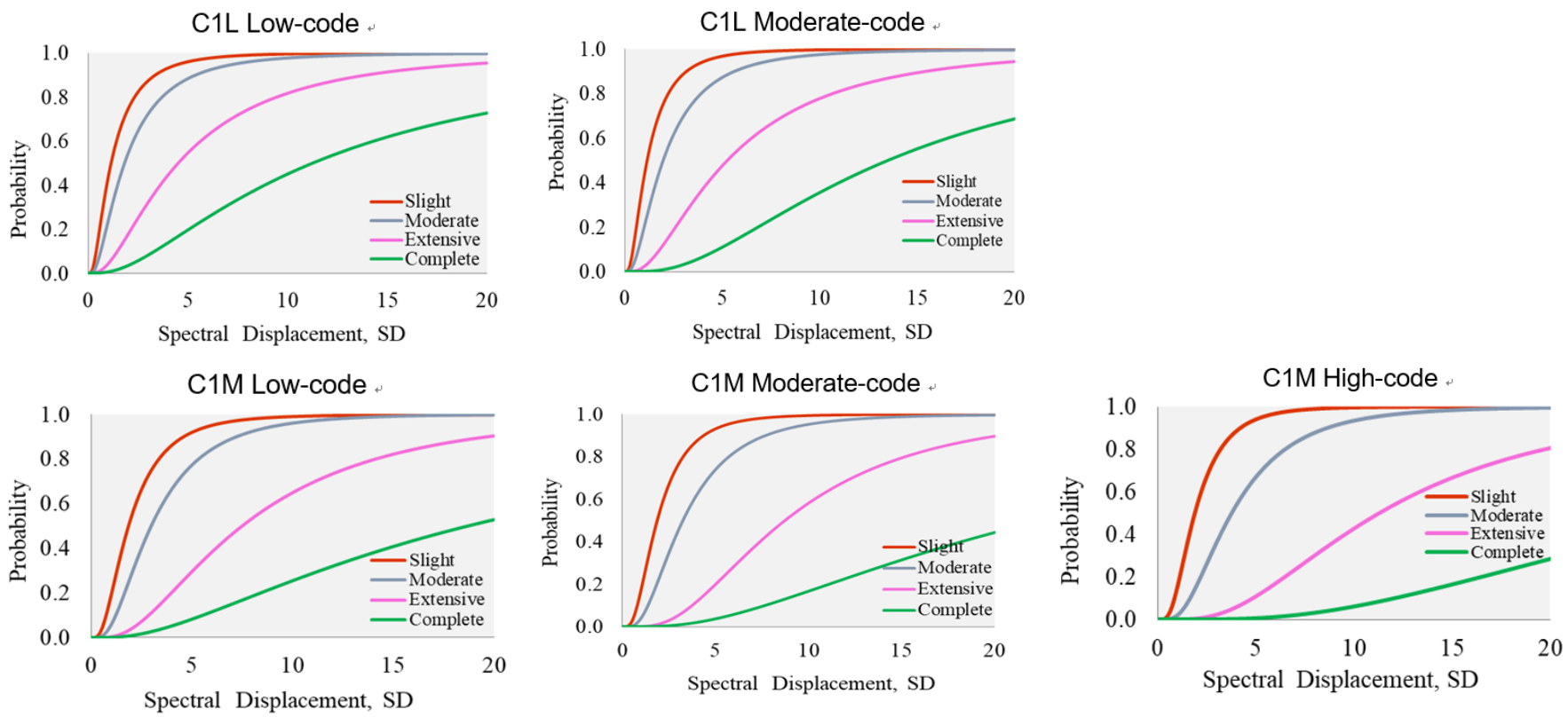

Figure 6. Fragility curve of each typical hospital buildings 
Table 6. Peak response building value of each hospital building

\begin{tabular}{llllll}
\hline Hospital building & $S_{d}$ & $P\left[S / S_{d}\right]$ & $P\left[M / S_{d}\right]$ & $P\left[E / S_{d}\right]$ & $P\left[C / S_{d}\right]$ \\
\hline Building A & 0.970 & $17.42 \%$ & $5.09 \%$ & $0.32 \%$ & $0.09 \%$ \\
Building B & 0.560 & $19.01 \%$ & $6.41 \%$ & $0.39 \%$ & $0.00 \%$ \\
Building C & 0.680 & $5.42 \%$ & $0.43 \%$ & $0.00 \%$ & $0.00 \%$ \\
Building D & 0.518 & $16.48 \%$ & $5.30 \%$ & $0.29 \%$ & $0.00 \%$ \\
Building E & 0.522 & $16.72 \%$ & $5.40 \%$ & $0.30 \%$ & $0.00 \%$ \\
Building F & 0.650 & $5.47 \%$ & $0.81 \%$ & $0.00 \%$ & $0.00 \%$ \\
Building G & 0.680 & $27.51 \%$ & $12.61 \%$ & $1.59 \%$ & $0.16 \%$ \\
Building H & 0.640 & $25.18 \%$ & $11.19 \%$ & $1.33 \%$ & $0.13 \%$ \\
Building I & 0.440 & $11.92 \%$ & $3.47 \%$ & $0.16 \%$ & $0.00 \%$ \\
Building J & 0.700 & $6.83 \%$ & $1.10 \%$ & $0.01 \%$ & $0.00 \%$ \\
Building K & 0.638 & $25.06 \%$ & $11.12 \%$ & $1.32 \%$ & $0.13 \%$ \\
Building L & 0.415 & $10.53 \%$ & $2.96 \%$ & $0.13 \%$ & $0.00 \%$ \\
Building M & 0.635 & $24.89 \%$ & $11.01 \%$ & $1.30 \%$ & $0.12 \%$ \\
Building N & 0.620 & $24.00 \%$ & $10.49 \%$ & $1.21 \%$ & $0.11 \%$ \\
Building O & 0.850 & $13.00 \%$ & $3.38 \%$ & $0.18 \%$ & $0.06 \%$ \\
\hline
\end{tabular}

\begin{tabular}{|l|l|l|l|l|l|}
\hline & 18.00 \\
\hline
\end{tabular}

Figure 7. Damage probability value of each hospital building in each damage state

The lowest value of damage probability for moderate, extensive, and complete levels occurs in Building $\mathrm{L}$, with values of $7.568 \%$; $2.832 \%$; $0.125 \%$; and $0.001 \%$, respectively. However, a high seismic design code level was used, despite being situated at the closest distance to the epicenter. This triggered the incidence of a wreckage due to lower earthquake scenario. The peak output was obtained at the lowest level (slight), while the least significant value was acquired at the highest level (complete). This findings indicate the higher propensity for minor damages to the hospital structures investigated rather than major.

\section{CONCLUSION}

The damage probability assessment of hospitals and other essential buildings is crucial as a disaster mitigation effort. Based on the evaluation using the 2006 Yogyakarta earthquake scenario for fifteen buildings, the 
closest distance to the epicenter for buildings with the same model type was determined to have the highest damage values. In addition, other major parameters involved in this appraisal include the height of the building story and the seismic or construction design standards used. Particularly, the fragility curves show a combination of low seismic design level, high building story, close proximity to the epicenter and high damage possibility. Also, all the structures investigated tend to have a greater chance for minor, compared to moderate or severe destruction. This study is expected to serve as an initial information source for further research, alongside other methods and earthquake scenarios with potentially high magnitude for future events. Furthermore, the research is particularly related to essential facilities, including primary communication institutes, fire, police and power stations, disaster or emergency operations centers, shelter, and other utilities required in a disastrous situation.

\section{DISCLAIMER}

The opinions and conclusions expressed in this manuscript are of the researchers. These authors do not have an associative benefit to prompt a conflict of interest in this study.

\section{ACKNOWLEDGMENTS}

The authors are grateful to the Earthquake Engineering Laboratory, Gifu University, Japan and Directorate of Research and Community Services (DPPM), Universitas Islam Indonesia, Yogyakarta, for the technical and financial support during this study.

\section{REFERENCES}

Badan Standardisasi Nasional, 2002. Tata Cara Perhitungan Struktur Beton untuk Bangunan Gedung (Beta Version). SNI 03-2847-2002. Bandung.

Bawono, A.S., 2016. Studi Kerentanan Bangunan Akibat Gempa: Studi Kasus Perumahan Di Bantul. Jurnal Ilmiah Semesta Teknika, Universitas Muhammadiyah Yogyakarta, 19(1), pp. 90-97.
Boore, D.M., Joyner, W.B., \& Fumal, T.E., 1997. Equations for Estimating Horizontal Response Spectra and Peak Acceleration from Western North American Earthquakes: A Summary of recent Work, Seismological Research Letters, 68 (1), pp.128-153.

Department of Public Works, 1991. Tata Cara Perhitungan Struktur Beton untuk Bangunan Gedung. SK SNI T-15-1991-03. Bandung: LPMB Foundation.

Department of Public Works and Electric Power, 1971. Peraturan Beton Bertulang Indonesia. PBI1971. Bandung: Direktorat Penyelidikan Masalah Bangunan.

Eleftheriadou, A.K., Baltzopoulou, A. D., and Karabinis, A. I., 2014. Seismic Risk Assessment of Buildings in the Extended Urban Region of Athens and Comparison with the Repair Cost. Open Journal of Earthquake Research, 3, pp.115134.

Elnashai, A.S., Kim, S.J., Yun, G.J., \& Sidarta, D., 2006. The Yogyakarta Earthquake of May 27th, 2006, Mid-America Earthquake Center Report No.07-02. Urbana : University of Illinois Champaign.

Faizah, R. \& Syamsi, M.I., 2017. Rapid Vulnerability Assessment of Muhammadiyah School Buildings due to Earthquake in Kasihan Bantul DIY. Jurnal Ilmiah Semesta Teknika, Universitas Muhammadiyah Yogyakarta, 20(2), pp. 164-171.

Federal Emergency Management Agency (FEMA), 1992. NEHRP Handbook for the Seismic Evaluation of Existing Buildings. FEMA 178. Washington, D.C.: FEMA Publication.

Federal Emergency Management Agency (FEMA), 1999. Earthquake Loss Estimation Methodology HAZUS 99: technical Manual. Washington, D.C.: FEMA Publication.

Federal Emergency Management Agency (FEMA), 2003. Multi-hazard Loss Estimation Methodology - Earthquake Model HAZUS ${ }^{\oplus M}$ MR4: 
Technical Manual. Washington, D.C.: FEMA Publication.

Gentile, R., Galasso, C., Idris, Y., Ruysdy, I. \& Meilianda, E., 2019. From Rapid Visual Survey to Multi-Hazard Risk Prioritization and Numerical Fragility of School Buildings. Natural Hazards and Earth System Sciences, 19, pp. 1365-1386.

Google Maps, 2019. Yogyakarta, Indonesia region. [Online] Available at: https://www.google.com/maps/place/Yogyakart a/ [Accessed 18 January 2019].

Kurniawandy, A., Hendri, A., \& Firdaus, R., 2015. Evaluasi Kerentanan Bangunan Gedung Terhadap Gempa Bumi Dengan Rapid Visual Screening (RVS) Berdasarkan FEMA-154. Annual Civil Engineering Seminar, Pekanbaru.

Muntafi, Y., 2016. Seismic Vulnerability Assessment of Hospital Building as Critical Facilities in North Side of Jakarta using HAZUS Method. Fourth International Conference on Sustainable Built Environment (ICSBE), Yogyakarta, pp.660-669.

Muntafi, Y., Faraodi, R., \& Asroni, A., 2018. Damage and Loss Probability Assessment of Reinforced Concrete Building due to Yogyakarta Earthquake Scenario Using Pushover and HAZUS analysis (case study: student center building, faculty of social science, UNY). International Conference of Disaster Management (ICDM). Padang, Indonesia, 229, pp.1-9.

National Development Planning Agency (Bappenas), 2006. A Joint Report - Preliminary Damage and Loss Assessment: Yogyakarta and Central Java Natural Disaster. The $15^{\text {th }}$ Meeting of
Consultative Group on Indonesia. Jakarta, June 14, 2006.

National Institute of Building Sciences (NIBS), 2002. HAZUS'99: Earthquake Loss Estimation Methodology: technical manual. In: FEMA (Editor), Technical Manual. Washington, D.C.: FEMA Publication.

National Standardization Agency (BSN), 2001. Standar Perencanaan Ketahanan Gempa Untuk Struktur Bangunan Gedung dan Non Gedung, SNI 03-1726-2002. Jakarta: BSN.

National Standardization Agency (BSN), 2012. Tata Cara Perencanaan Ketahanan Gempa untuk Struktur Bangunan Gedung dan Non Gedung, SNI 1726:2012. Jakarta: BSN.

National Standardization Agency (BSN), 2013. Persyaratan Beton Struktural untuk Bangunan Gedung, SNI 2847:2013. Jakarta: BSN.

Pusat Studi Gempa Nasional (PUSGEN), 2017. Peta Sumber dan Bahaya Gempa Indonesia Tahun 2017. Pusat Litbang Perumahan dan Pemukiman, Kementerian Pekerjaan Umum dan Perumahan Rakyat (National Center for Earthquake Studies. Indonesian Seismic Sources and Seismic Hazard Maps 2017). Bandung: Center for Research and Development of Housing and Resettlement, Ministry of Public Works and Human Settlements.

Saputra, A., 2012. Pengurangan Risiko Gempabumi Melalui Evaluasi Bangunan Tempat Tinggal Dan Lingkungannya di Kecamatan Pleret Kabupaten Bantul. Yogyakarta: Master Thesis Report. Department of Civil and Environmental Engineering. Universitas Gadjah Mada. 